\title{
The Effects of the Covid-19 Pandemic on Organized Crime Activities in the Society 5.0
}

\author{
Covid-19 Pandemisinin Toplum 5.0'da Organize Suç Faaliyetlerine Etkisi
}

\author{
PASQUALE PELUSO* \\ * Assoc. Prof., Università degli Studi “Guglielmo Marconi” di Roma, Via Plinio, 4400193 Rome, Italy, \\ E-mail: p.peluso@unimarconi.it \\ (D) https://orcid.org/0000-0002-9004-1812
}

\begin{abstract}
The paper aims to analyze the effects that the Covid-19 pandemic has had on the illegal activities carried out by organized crime. Organized criminal groups have shown that they are able to quickly identify the sectors that can ensure greater earnings by exploiting the economic and health crisis due to the spread of Covid-19. The paper highlights how Society 5.0, through its inspiring principles, can offer valid tools for combating illegal activities carried out by organized crime.
\end{abstract}

Keywords: Organized crime, Society 5.0, Covid-19 pandemic, Illegal economy, Organized crime and pandemic

Öz: Makale, Covid-19 pandemisinin organize suçların gerçekleştirdiği yasadışı faaliyetler üzerindeki etkilerini analiz etmeyi amaçlamaktadır. Organize suç grupları, Covid-19'un yayılması nedeniyle yaşanan ekonomik ve săglık krizini istismar ederek daha fazla kazanç sağlayabilecek sektörleri hızl bir şekilde tespit edebildiklerini göstermiştir. Belge, ilham verici ilkeleri aracılığıla Society 5.0'n organize suçlar tarafindan gerçekleştirilen yasadışı faaliyetlerle mücadele için nasıl geçerli araçlar sunabileceğini vurgulamaktadır.

Anahtar kelimeler: Örgütlü suç, Toplum 5.0, Covid-19 pandemisi, Yasadışı ekonomi, Örgütlü suç ve pandemi

\section{Introduction}

The pandemic due to the spread of Covid-19 has profoundly affected everyone's habits and lifestyles. The lockdown also had profound repercussions from an economic point of view, causing a global crisis with a recession phase in every Country. The situation of economic stagnation has caused a collapse in the demand for goods and services. To this must be added the growth in the unemployment rate. In this context, the possibility of counting on a certain liquidity for companies has become vital.

The different forms of lockdown that have occurred in all States have led to a shift towards the digital world and the online market for social and economic activities. To try to reverse the negative trend and restart the economy, the European Union has allowed each State to provide economic incentives for the various professional 
categories and citizens in the form of bonuses and compensations. These bonuses have constituted a particularly important flow of liquidity which has obviously attracted the attention of organized crime groups.

\section{State of Emergency and Criminal Business}

It should be noted that the emergency, especially in Italy since the $1980 \mathrm{~s},{ }^{1}$ has represented the best ally for those business that must be done quickly and in the shadows. History has shown that corruption and emergencies go hand in hand and are necessary for each other to exist. Between emergencies and corruption, bad management is created that takes on the appearance of a vicious circle that leads to an irreparable crisis. ${ }^{2}$ The changes have also influenced organized crime groups which know how to exploit economic crises and historical moments in which great changes occur. ${ }^{3}$ Organized crime has taken advantage of the crisis caused by the pandemic both to move their money faster and to try to take advantage of the fewer controls of the authorities to launder money. ${ }^{4}$

It is necessary to emphasize the need for a law enforcement action evaluated and implemented at a supranational level, at least at a European, if not global level. In fact, to believe that organized crime groups constitute a delimited or delimitable phenomenon in certain geographical areas in which it can rely on a solid organization is not only limited but also misleading. Furthermore, such an idea has a decisive influence on the effectiveness of the law enforcement tools implemented by the various national laws. ${ }^{5}$ A shared knowledge of the criminal phenomenon, of the modus operandi of the factions, of the networks they can rely on, can facilitate the implementation of law enforcement activities at European level. Otherwise, however, a great advantage is granted to organized crime "in terms of expansion to other economies". ${ }^{6}$

Criminal groups have tried to exploit the situation of consumption crisis and lack of liquidity to put money of illicit origin on the marketplace, creating a flow of money laundering and usury that has also been defined as "financial doping".

\section{Covid Economy and Infiltration of Criminal Organizations in the Legal Economy}

In the literature, the economy generated by the pandemic is called the "Covid Economy". In the period of maximum spread of the virus, with the stagnation of the economy, large sums of money were distributed to cope with the economic crisis that the health emergency had caused. However, the rapid and urgent disbursement of economic aid that could be a stimulus for the recovery of the economy combined with the risk of possible external influence on political responses,

\footnotetext{
${ }^{1}$ Francesco Barbagallo, Il Potere Della Camorra, Torino: Einaudi, 1999.

${ }^{2}$ Transparency International, Corruption Perceptions Index 2020, Belin: Transparency International Ed., 2021.

${ }^{3}$ Wesley G. Jennings and Nicholas M. Perez, "The Immediate Impact of COVID19 on Law Enforcement in the USA", American Journal of Criminal Justice, 45 (2020): 690-701.

${ }^{4}$ Vincenzo Maiello and Luca Della Ragione L., eds., Riciclaggio E Gestione Dei Flussi Di Denaro Sporco, Napoli: Giuffré, 2018.

${ }^{5}$ Salvatore Lupo, La Mafia: Centosessant'anni Di Storia, Roma: Donzelli, 2018.

${ }^{6}$ Riccardo Tonelli, "L'emergenza del Covid-19 e il Condizionamento Dell'economia Legale da Parte Della Criminalità Organizzata”, Diritto Virale, 1/7 (2021), p.22.

${ }^{7}$ Organismo Permanente di Monitoraggio e Analisi sul Rischio di Infiltrazione Nell'economia da Parte Della Criminalità Organizzata di Tipo Mafioso, Report 1/2020, Roma: Ministero dell'Interno, 2020, p.2.
} 
constitute fertile land for corruption. ${ }^{8}$ The investigations have shown that in Italy the criminal organized groups during the lockdown have continued to act secretly without attracting attention, with a decrease in "first level criminal activities"9 (drug trafficking, extortion, receiving stolen goods, robberies), but an increase in the North and Center of money laundering cases and, in the South, cases of political-mafia electoral exchange and corruption.

First of all, the Covid Economy has produced usury and corruption. In a historical moment in which access to credit is difficult, usury guarantees liquid and cash money that allows families to continue to have expenses, for companies to be able to bear the costs despite lost earnings. Usury allows the economy to continue running but pollutes it irreparably. Corruption can undermine the response that Governments must give to people to fight the pandemic and deprive people of health care. It should be borne in mind that in normal times corruption in the health sector is particularly present and causes losses of over 500 billion dollars a year. ${ }^{10}$

In Italy in the first quarter of 2020, while crimes such as robberies, thefts and extortion recorded a significant decrease, usury was the only crime that recorded an increase of about $10 \%$ compared to the same period of the previous year. ${ }^{11}$ Regarding to corruption, Italy, while improving its score, continues to occupy low positions, placing itself, according to Transparency International, at 52 place in the ranking, remaining subjected to high pressures due to the COVID- $19^{12}$ pandemic. COVID-19 was not just a health and economic crisis, it represented the corruption crisis that States have failed to manage. ${ }^{13}$

The possible risk of mafia infiltration following the COVID-19 epidemic has been highlighted in three different areas: the acquisition of companies that need to recapitalize to address the losses accumulated during the coronavirus pandemic; the bankruptcy of companies that have failed to honor the loans taken out at usurious rates in order to obtain liquidity; the ever-increasing attempt to obtain financing for economic recovery. ${ }^{14}$

The European institutions are well aware of the risk of the European financial system as it is more easily possible in some States, than in others, to hide dirty money. Measures to support the economy tend to take away space from organized crime. But the risk is that with the money of criminal organizations not only the economy is fed but also the welfare system is kept alive. ${ }^{15}$ The organized crime, in fact, uses a supranational branched structure that best fits the needs of capitalism enabling the understanding of the market sectors that have a greater chance of gain. The most marked propensity of organized crime is to promptly understand any change

\footnotetext{
${ }^{8}$ Europol, Beyond The Pandemic How COVID-19 Will Shape the Serious and Organised Crime Landscape in the EU, European Union Agency for Law Enforcement Cooperation, 2020.

${ }^{9}$ Ministero dell'Interno, Relazione Del Ministro Dell'interno Al Parlamento Sull'attività Svolta E Sui Risultati Conseguiti Dalla Direzione Investigativa Antimafia, 1 Semestre 2020 Semestre (Gennaio- Giugno 2020), Roma, 2021, p.318.

${ }^{10}$ Rachel Cooper, Sarah Steingrüber and Tom Wright, The Ignored Pandemic. How Corruption In Healthcare Service Delivery Threatens Universal Health Coverag, Berlin: Transparency International Ed., 2019.

${ }^{11}$ Organismo Permanente Di Monitoraggio E Analisi Sul Rischio Di Infiltrazione Nell'economia Da Parte Della Criminalità Organizzata Di Tipo Mafioso, Report 2/2020, Roma: Ministero dell'Interno, 2020.

${ }^{12}$ Transparency International, Corruption, 2021.

${ }_{13}$ Trasparency International, Corruption, 2021, p.8.

${ }^{14}$ Michele Fabrizi and Antonio Parbonetti, "Aziende Criminali, Business E Covid-19: I Rischi Nascosti Della Pandemia”, Economia E Società Regionale, 38/2 (2020), p.66.

${ }^{15}$ Eurispes, Rischio Infiltrazioni Delle Mafie, 12/2020, Roma, 2020.
} 
in the economic order, to evaluate the new economic and financial trends of the market to get the maximum benefit. ${ }^{16}$ Furthermore, the liquidity available for these criminal organizations allows them to act quickly and without bureaucratic constraints.

For these reasons, criminal organizations are able to infiltrate and alter entire economic sectors such as the agro-food chain, the sector for the supply of medicines and medical supplies, the logistics sector, the waste disposal chain, and now the sector of cleaning and sanitation companies. ${ }^{17}$

In these sectors the activities have never been interrupted and this has allowed the criminal organizations to consolidate their sphere of influence in order to try to strengthen the mafia welfare that leads to social consensus criminal associations. ${ }^{18}$

The forms of financing guaranteed by the State for companies in difficulty, have also attracted the attention of organized criminal groups. Particularly long times for the disbursement of the sums can entail the risk of an alteration of the procedures with consequent diversion of resources with respect to the legitimate purposes. ${ }^{19}$

Social support for citizens in difficulty constitutes an important area in which criminal organizations organize and manage forms of protest against the lack of intervention by the State. Families in difficulty, illigal workers, who face lack of income, represent an important pool for criminal gangs that can offer their support with assistance sustenance activities aimed at recruiting low-cost laborers. In addition, all the major organized criminal groups in Italy have favored the use of telematic tools, that are not easily intercepted, to maintain the necessary relationships for carrying out criminal activities, to conclude transactions or make agreements.

The risk of usury by criminal organizations hangs both on precarious workers or illegal workers and on entrepreneurs. The former may be asked to vote at the appropriate time for certain candidates linked to the criminal organization or who may be asked to carry loads of drugs or sell or keep weapons. The money offered to entrepreneurs to pay the debts or salaries of employees is the instrument of pressure aimed at expropriating the business.

Finally, large public funds aimed at reviving the economy through the financing of public works is another area in which criminal organized groups are particularly interested in trying to acquire availability through corrupt practices to win public contracts. In some Italian regions there are known infiltrations of organized crime in some sectors that benefit from state and EU public funding and following the coronavirus emergency the presence of such associations could also consolidate. Monopoly control of some economic activities brings attention back to the world connected to the health sector. If we consider that in some territories the Public

\footnotetext{
${ }^{16}$ Ministero dell'Interno, Relazione Del Ministro Dell'interno Al Parlamento Sull'attività Svolta E Sui Risultati Conseguiti Dalla Direzione Investigativa Antimafia.

${ }^{17}$ Nicola Gratteri and Antonio Nicaso, Ossigeno Illegale. Come Le Mafie Approfitteranno Dell'emergenza Covid-19 Per Radicarsi Nel Territorio Italiano, Milano: Mondadori, 2020.

${ }^{18}$ Pasquale Peluso, "Usura, Pandemia e Composizione Della Crisi da Sovraindebitamento", Rivista Italiana di Conflittologia, 40/2020, pp. 63-82.

${ }^{19}$ Unità di Informazione Finanziaria per l'italia, Prevenzione di Fenomeni di Criminalità Finanziaria Connessi Con L'emergenza da COVID-19, Comunicazione del 16.04.2020.
} 
Administration is under great pressure regarding the award of public contracts which during the epidemic take place in the form of direct assignment, justified by circumstances of necessity and urgency, evading the necessary assignment checks.

Furthermore, organized crime has tried to illegally access the measures to support the economy (compensations) launched by the Italian government using methods similar to those used by classic economic-financial crime such as the falsification of tax documents, the instrumental use of some companies, the involvement of that gray area ${ }^{20}$ that makes expert professionals available to criminal organizations to infiltrate.

The health emergency has therefore created countless opportunities for illicit profits that go beyond usury, resulting in various cases of corruption, scams, cheats and web crimes. ${ }^{21}$

A particularly interesting data for Italy is the $7 \%$ increase in reports for suspicious transactions and an increase of about $10 \%$ in the companies affected by anti-mafia interdicting measures compared to the same period of the previous year. ${ }^{22}$ This highlights not only that criminal organizations have never stopped but have also further infiltrated some sectors. With reference to a series of data relating to company changes, transfers of shares, changes of a legal nature or ownership of the share capital, in the period from March 2020 to February 2021 compared to the same period of the previous year, there was an increase the number of banned companies $(+9.7 \%)$ and in particular the number of banned companies that had registered a corporate change $(+47 \%){ }^{23}$

The instrument of corporate change, therefore, still constitutes the main mechanism used by organized criminal groups to penetrate the legal productive economic fabric and pollute it. The construction sector is the sector most represented by the companies receiving anti-mafia bans. The regions in which there was a greater number of corporate changes are Calabria, Sicily and Campania.

Additional sectors particularly exposed to the coronavirus crisis are those of catering and hotel hospitality.

Furthermore, in these sectors, the highest risk of money laundering had already been reported since these activities are characterized by frequent use of cash, high levels of irregular labor and poor transparency of the corporate structure. These elements, combined with the other risk factors represented by the number of organized criminal associations, the number of predicate crimes and the amount of cash, raise the money laundering risk both at sectoral and territorial level. ${ }^{24}$

Organized crime has exploited the increase, during the emergency phase, of the demand for health devices such as individual protection devices, electro-medical devices, sanitizing products, placing counterfeit products on the market or products that do not meet the required standards. Worldwide, shortages of medicines

\footnotetext{
${ }^{20}$ Rocco Sciarrone, Le Mafie Nell'economia Legale, Bologna: Il Mulino, 2019.

${ }^{21}$ Organismo Permanente Di Monitoraggio E Analisi Sul Rischio Di Infiltrazione Nell'economia Da Parte Della Criminalità Organizzata Di Tipo Mafioso, Report 5/2021, Ministero dell'Interno, Roma, 2021.

22 Organismo, Report 1/20, 2020.

${ }^{23}$ Organismo, Report 5/21, 2021.

${ }^{24}$ Ernesto Ugo Savona and Michele Riccardi M., eds., Assessing the Risk of Money Laundering in Europe. Final Report of Project IARM, Milano: Transcrime-Università Cattolica del Sacro Cuore, 2017.
} 
and medical supplies have been reported due to the coronavirus. This puts a strain on procurement processes and increases the risk that suppliers, abusing the State's need to supply, raise prices knowing that governments have no choice but to pay. Among the illegal practices put in place there are also speculative maneuvers on health care facilities which have led to a disproportionate increase in the purchase price with huge profits for the companies engaged in the sale. In some cases there has been a disproportionate storage of supplies such as masks, gloves, hand sanitizer which, on the one hand, caused a shortage of supplies, on the other, led to an increase in prices not only for ordinary consumers. ${ }^{25}$

Often the health facilities or electromedical devices were lacking, if not completely lacking, of the required documentation and certifications, highlighting the counterfeiting of these products. ${ }^{26}$ In some cases there have been proposals for the subscription and sale of shares of companies that carried out their activity in the field of medical research or in the production of particular health devices. ${ }^{27}$

Organized crime groups, in an unscrupulous way, have used crowdfunding platforms for the collection of online funds in favor of non-profit organizations and associations to collect money paid to organizations that do not exist or which can be traced back to members of these factions, exploiting their particular status of the subjects who were asked to make an offer online.

Lastly, the progressive shift of economic and social activities towards the digital world has led to an increase in online activities. This has been a particular attraction for criminal associations that have carried out further online crimes in addition to traditional forms of cybercrime, exploiting the increase in network users. In fact, phishing episodes and attacks on personal computers have increased in Italy by exploiting malware by sending documentation relating to Covid-19 or to accredited health organizations to company e-mail addresses. ${ }^{28}$

No one was immune to these attacks: from students connected from home to follow school lessons, to workers who carried out their business from home through personal computers, to health organizations that carried out assistance activities for those who had contracted the virus, to institutions governmental.

\section{The Effects of the Infiltration of Criminal Groups in the Legal Economy and Possible Law Enforcement Activities}

The concern of citizens about the possible contagion from corona virus, the offer of sanitation activities with innovative products and at bargain prices, the offer of treatment programs that can only be activated online, the proposal of innovative forms of prevention through patented products by international companies offered at bargain prices have certainly influenced the success of cyber attacks.

All online activities have been exploited by criminal associations who have also speculated on the greater presence of minors on the network due in part to the

\footnotetext{
${ }^{25}$ Jeffrey Dastin, Amazon Bars One Million Products For False Coronavirus Claims, Reuters, 27.02.2020.

${ }^{26}$ United Nations Office on Drugs and Crime, COVID-19-related Trafficking of Medical Prodicts as a Threat to Public Health, UNODC Research and Trend Analysis Branch, Vienna, 2020.

${ }^{27}$ Vincenzo Vallefuoco, Crimini E Pandemia: 6 Reati Da Cui Guardarsi Ai Tempi Del Coronavirus, Il sole 24 ore, 23.06.2020.

${ }^{28}$ Europol, How Criminals Exploit The Covid-19 Crisis, March 2020, European Union Agency for Law Enforcement Cooperation, 2020.
} 
need to follow the educational activities at a distance and in part to the sociality that has only moved online. ${ }^{29}$

After "the medical infection of the virus" will follow the "Mafia financial infection" which, in order to be averted, requires procedures "adapted" to the current scenario. Indeed, their "intelligent simplification" becomes indispensable. ${ }^{30}$

Also for this reason it is clear that first of all it is necessary to block the infiltration and conditioning activities by organized crime from the outset. However, tools of a purely repressive nature do not appear useful on their own. In fact, complex solutions are needed to effectively combat a particularly extensive and complex phenomenon. Although the repressive apparatus plays a role of primary importance, it should be noted that the repression of economic/financial crimes requires high specialization on the part of law enforcement bodies and forms of international collaboration. Furthermore, the repression takes place at a later stage than the one in which the crime has already occurred. The pervasiveness of organized criminal activity leaves the reference economic and social fabric empty and compromises its development possibilities. ${ }^{31}$

It appears essential, especially during the economic emergency caused by the pandemic, to combine the repressive action with those actions constantly implemented by the Public Administration and which consist of preventive measures of an administrative nature suitable for preventing the infiltration of organized crime into the legal economy. Only in this way is it possible to identify those virtuous economic operators who are outside the so-called gray area. At the same time, it is possible to identify those subjects who, although not part of criminal associations, are nevertheless attracted to the criminal world and would be ready to enter into business with organized crime.

Implementing these preventive measures is not simple and above all requires a great deal of energy in terms of controls. The work that must be done to evaluate and screen documents is often unsustainable due to the scarcity of human resources and technical tools. Therefore, these controls, especially when aimed at issuing certifications, can affect the prevention activity if the quality of the same is not optimal. ${ }^{32}$ Ineffective controls, then, could have the opposite effect and that is to favor the permanence in the legal markets of companies that fall within the gray area through the granting of certifications and the consequent benefits. ${ }^{33}$

The Covid-19 emergency has entailed and will entail a series of further checks for participation in the benefits provided for by public intervention measures and for participation in tenders. This amount of work is difficult to reconcile with the need for speed and quality of controls. One of the proposals supported by various institutional actors, in addition to the conventional control ones, is to develop a culture

\footnotetext{
${ }^{29}$ Europol, How Covid-19-Related Crime Infected Europe During 2020, European Union Agency for Law Enforcement Cooperation, 2020.

${ }^{30}$ Ministero dell'Interno, Relazione del Ministro dell'Interno al Parlamento sull'attività svolta e sui risultati conseguiti dalla Direzione Investigativa Antimafia.

${ }^{31}$ Vittorio Mete, "Le Mafie Nell'autotrasporto. Il Caso di Reggio Emilia", Mafie, Legalità, Lavoro: Numero Monografico Di Quaderni di Città Sicure, 42/24 (2018): 11-37.

${ }^{32}$ Nando Dalla Chiesa and Federica Cabras, Rosso Mafia: La 'Ndrangheta A Reggio Emilia, Milano: Bompiani, 2019.

${ }^{33}$ Gianni Belloni and Antonio Vesco, Come Pesci Nell'acqua: Mafie, Impresa e Politica in Veneto, Roma: Donzelli, 2018.
} 
of participation and legality in which civil society plays an important role by identifying virtuous operators and making them enjoy a positive reputational effect. This effect should offer less permeability to the conditioning of organized crime. Prevention activities are decidedly important considering that the Anti-Mafia Investigation Department has already highlighted in its report for the first half of 2020 that the economic paralysis caused by the pandemic has assumed macro dimensions that offer prospects of enrichment and expansion to the criminal gangs comparable only to the rhythms growth that occurred in the post-war periods.

\section{The Possible Support of Society 5.0 in the Fight against Organized Crime}

Never before in this context has it become useful to refer to the concept of Society 5.0 introduced to relaunch industrial innovation and today used in a vision dictated by considerations linked to the prospects of growth and stability of the system with sustainable development and an economy tailored to the needs of the 'man. The news and what has been said so far have highlighted how the explosion of an epidemic has brought to its knees, in the space of a few weeks, some key principles on which modern democracies are based: free movement of people, goods, capital, technological efficiency in monitoring some variables, opportunities to support and protect the weakest social groups. ${ }^{34}$ Technology is and must continue to be a tool at the service of society that can be used to support what was previously highlighted. It is true that the massive use of digital technologies can conflict with civil liberties, with privacy, with the freedom of movement and movement of individuals, being able to become instruments of control and surveillance, but it is also true that innovation technology, and in particular artificial intelligence, can be used to support society in those awkward or burdensome tasks. In a world that is constantly changing and characterized by fast and impactful technological development, Society 5.0 intends to place man at the center of choices in various fields, from social to economic and cultural ones. And with this in mind, the vision of a more inclusive society, digitization at the service of mankind and not the other way around, should be exploited to raise social sustainability. Innovation understood as the improvement of human conditions allows, especially for societies where evolution and change is rapid, to intercept the opportunities for change to prevent the aforementioned phenomena, ${ }^{35}$ but it is also true that technological innovation, and in particular artificial intelligence, can be used to support society in those awkward or burdensome tasks. In a world that is constantly changing and characterized by fast and impactful technological development, Society 5.0 intends to place man at the center of choices in various fields, from social to economic and cultural ones. And with this in mind, the vision of a more inclusive society, digitization at the service of mankind and not the other way around, should be exploited to raise social sustainability. Innovation understood as the improvement of human conditions allows, especially for societies where evolution and change is rapid, to intercept the opportunities for change to prevent the aforementioned phenomena. ${ }^{36}$

Through artificial intelligence that analyzes indefinite amounts of data through algorithms, that predictive analysis can be carried out that is able to detect, through mathematical models, the most important trends and suggest the measures to be

34 Fabio Bocci, "Un Modo Umano Di Organizzarci. Le Logiche Dei Confini Nel Tempo Della Medicalizzazione: Scenari E Possibili Vie Di Uscita", Cooperazione Educativa. 68/3 (2019): 26-32.

${ }^{35}$ David Lyon, The Culture of Surveillance: Watching As a Way of Life, Polity Press, Cambridge, 2018.

${ }^{36}$ Hitachi-UTokyo Laboratory, Society 5.0. A People-centric Super-smart Society, Springer, Singapore, 2020. 
taken. Big Data analysis and the use of artificial intelligence algorithms make it possible to anticipate a crime before it is committed. Indeed, another important goal of Society 5.0 is to avoid that information is concentrated as in the past. In this sense, it will be fundamental for the Public Administration to define a strategy to implement the concept of Society 5.0. In addition, the Public Administration, in addition to being precise and virtuous in the construction of tenders and technical specifications to avoid unpleasant episodes and have to strengthen, the strategies to combat organized crime and avoid problems of its infiltration into the legal economy.

\section{Conclusions}

Technology can allow faster traceability of financial flows deriving from loans to businesses to ensure the correct destination of the resources disbursed and their lawful use. The work carried out by men remains important, in particular, the activity carried out by the Financial Intelligence Unit which in Italy monitors operations in Italy, reporting suspicious ones to the Guardia di Finanza and the AntiMafia Investigation Department is relevant. The police forces are therefore entrusted with monitoring the signals that may indicate a change in the strategies of the mafia factions.

The preventive anti-mafia control carried out centrally by the Central Interforces Group at the Criminal Police, by the Central Public Procurement Observatory at the Anti-Mafia Investigation Department remains essential to prevent the infiltration of criminal associations into the legal economy of the public procurement system.

It is clear that it is not possible to assess the effects of the health emergency on crime in the short term. The effects in the short term are those related to crimes such as usury, corruption and computer crimes, converging in phishing campaigns, ransomware, malware and online scams. In the long term, to avoid further consequences deriving not only from criminal activity but also from the economic crisis in the case of new and further lockdowns or other restrictive measures on an emergency basis, it is necessary to ride technological innovation and take the best of Society 5.0 to make It is possible to analyze and explain complex phenomena in the simplest form. This could be an effective weapon in the fight against organized crime.

\section{References}

Barbagallo, Francesco. Il Potere Della Camorra. Torino: Einaudi, 1999.

Belloni, Gianni and Antonio Vesco. Come Pesci Nell'acqua: Mafie, Impresa e Politica in Veneto. Roma: Donzelli, 2018.

Bocci, Fabio. "Un Modo Umano Di Organizzarci. Le Logiche Dei Confini Nel Tempo Della Medicalizzazione: Scenari E Possibili Vie Di Uscita". Cooperazione Educativa. 68/3 (2019): 26-32.

Cooper, Rachel, Sarah Steingrüber and Tom Wright. The Ignored Pandemic. How Corruption in Healthcare Service Delivery Threatens Universal Health Coverage. Berlin: Transparency International Ed., 2019.

Dalla Chiesa, Nando and Federica Cabras. Rosso Mafia: La 'ndrangheta a Reggio Emilia. Milano: Bompiani, 2019. 
Dastin, Jeffrey. Amazon Bars One Million Products for False Coronavirus Claims. Reuters, 27.02.2020.

Eurispes. Rischio infiltrazioni delle mafie. 12/2020 Roma, 2020.

Europol. Beyond the Pandemic How COVID-19 Will Shape the Serious and Organised Crime Landscape in the EU. European Union Agency for Law Enforcement Cooperation, 2020.

Europol. How Covid-19-Related Crime Infected Europe During 2020. European Union Agency for Law Enforcement Cooperation, 2020.

Europol. How Criminals Exploit The Covid-19 Crisis, March 2020, European Union Agency for Law Enforcement Cooperation, 2020.

Fabrizi, Michele and Antonio Parbonetti. "Aziende criminali, business e Covid-19: I Rischi Nascosti Della Pandemia”. Economia E Società Regionale, 38/2 (2020): 66-71.

Gratteri, Nicola and Antonio Nicaso. Ossigeno Illegale: Come Le Mafie Approfitteranno Dell'emergenza Covid-19 Per Radicarsi Nel Territorio Italiano. Milano: Mondadori, 2020.

Hitachi-UTokyo Laboratory. Society 5.0. A People-centric Super-smart Society. Singapore: Springer, 2020.

Jennings, Wesley G. and Nicholas M. Perez. "The Immediate Impact of COVID19 on Law Enforcement in the USA". American Journal of Criminal Justice. 45 (2020): 690-701.

Lupo, Salvatore. La Mafia: Centosessant'anni di storia. Roma: Donzelli, 2018.

Lyon, David. The Culture of Surveillance: Watching As a Way of Life. Cambrigde: Polity Press, 2018.

Maiello, Vincenzo and Luca Della Ragion. Eds., Riciclaggio E Gestione Dei Flussi Di Denaro Sporco. Napoli: Giuffré, 2018.

Mete, Vittorio. "Le Mafie Nell'autotrasporto. Il Caso Di Reggio Emilia". Mafie, Legalità, Lavoro: Numero Monografico Di Quaderni Di Città Sicure. 42/24 (2018): 11-37.

Ministero dell'Interno. Relazione Del Ministro Dell'interno Al Parlamento Sull'attività Svolta E Sui Risultati Conseguiti Dalla Direzione Investigativa Antimafia, 1 Semestre 2020. (Gennaio-Giugno 2020), Roma, 2021.

Organismo Permanente Di Monitoraggio E Analisi Sul Rischio Di Infiltrazione Nell'economia Da Parte Della Criminalità Organizzata Di Tipo Mafioso. Report 5/2021. Ministero dell'Interno, Roma, 2021.

Organismo Permanente Di Monitoraggio E Analisi Sul Rischio Di Infiltrazione Nell'economia Da Parte Della Criminalità Organizzata Di Tipo Mafioso. Report 1/2020. Ministero dell'Interno, Roma, 2020.

Organismo Permanente Di Monitoraggio E Analisi Sul Rischio Di Infiltrazione Nell'economia Da Parte Della Criminalità Organizzata Di Tipo Mafioso. Report 2/2020. Ministero dell'Interno, Roma, 2020.

Peluso, Pasquale. "Usura, Pandemia e Composizione Della Crisi da Sovraindebitamento". Rivista Italiana di Conflittologia, 40 (2020): 63-82.

Savona, Ernesto Ugo and Michele Riccardi. Eds. Assessing the risk of money laundering in Europe. Final Report of Project IARM. Milano: TranscrimeUniversità Cattolica del Sacro Cuore, 2017.

Sciarrone, Rocco. Le Mafie Nell'economia Legale. Bologna: Il Mulino, 2019. 
Tonelli, Riccardo. "L'emergenza Del Covid-19 E Il Condizionamento Dell'economia Legale Da Parte Della Criminalità Organizzata”, Diritto Virale, 1/7 (2021): 21-27.

Transparency International. Corruption Perceptions Index 2020. Berlin: Transparency International Ed., 2021.

Unità di Informazione Finanziaria per l'Italia. Prevenzione di Fenomeni di Criminalità Finanziaria Connessi Con L'emergenza da COVID-19, Comunicazione del 16.04.2020.

United Nations Office on Drugs and Crime. COVID-19-related Trafficking of Medical Prodicts as a Threat to Public Health. Vienna: UNODC Research and Trend Analysis Branch, 2020.

Vallefuoco, Vincenzo. Crimini E Pandemia: 6 Reati Da Cui Guardarsi Ai Tempi Del Coronavirus, Il sole 24 ore, 23.06.2020. 